\begin{tabular}{|l|l|l||}
\hline \multicolumn{2}{|c|}{ PublisherInfo } \\
\hline \hline PublisherName & $:$ & BioMed Central \\
\hline \hline PublisherLocation & $:$ & London \\
\hline \hline PublisherImprintName & $:$ & BioMed Central \\
\hline \hline
\end{tabular}

\title{
Doubling up the genome
}

\begin{tabular}{|l||l|l||}
\hline \multicolumn{2}{|c|}{ ArticleInfo } \\
\hline \hline ArticleID & $:$ & 4359 \\
\hline \hline ArticleDOI & $:$ & $10.1186 /$ gb-2002-3-8-reports0045 \\
\hline \hline ArticleCitationID & $:$ & reports0045 \\
\hline \hline ArticleSequenceNumber & $:$ & 26 \\
\hline \hline ArticleCategory & $:$ & Paper report \\
\hline ArticleFirstPage & $:$ & 1 \\
\hline \hline ArticleLastPage & $:$ & 3 \\
\hline \hline & & RegistrationDate : 2002-6-3 \\
ArticleHistory & $:$ & Received $\quad: 2002-6-3$ \\
& $:$ 2002-8-1 \\
\hline \hline ArticleCopyright & $:$ & BioMed Central Ltd2002 \\
\hline \hline ArticleGrants & $:$ & \\
\hline \hline
\end{tabular}




\begin{tabular}{|l|l|l|}
\hline ArticleContext & $:$ & 130593388 \\
\hline
\end{tabular}

\section{Jeffrey T Ehmsen}

\section{Summary}

The distribution of orthologous genes within the major histocompatibility complex paralogous regions of amphioxus and humans supports the idea of genome-wide duplication events in vertebrate evolution

\section{Significance and context}

Vertebrate genomes contain a number of gene families, often arranged in contiguous arrays on one or more chromosomes and present in varying copy number depending on the species. A contentious hypothesis posits that such families have arisen through genome duplication, which, if true, makes this an important feature of vertebrate evolution. Abi-Rached et al. compare major histocompatibility complex (MHC) regions between the genomes of amphioxus, a filter-feeding, fish-like cephalochordate predating the evolution of vertebrates, and present-day jawed vertebrates, Gnathostomata, represented by the human genome. The observed distribution of orthologous genes provides support for the view that some degree of polyploidization has indeed been a significant feature of vertebrate evolution.

\section{Key results}

Assuming that conserved syntenies between MHC regions in human and bony fish represent en bloc duplications that occurred before the Gnathostomata radiation, the authors cloned nine 'anchor genes' from an amphioxus cosmid library, sequenced 400 kilobases of regions flanking these genes, and ran a database search for similar sequences in the human genome. The 9 anchor genes and 22 surrounding genes and their counterparts in the human genome are considered to be orthologs, prompting the conclusion that duplications giving rise to the anchor-gene families occurred between 420 and 766 million years ago, after the divergence of cephalochordates and vertebrates but before the vertebrate radiation. The human orthologs of the genes surrounding the amphioxus anchor genes were mapped and their distribution within the four human MHC regions on chromosomes 1, 6, 9 and 19 were analyzed, revealing a statistically nonrandom organization indicative of an evolutionary link between the two genomes. To understand the development of the human MHC regions better, the authors used cloned amphioxus genes to reconstruct a 'proto-MHC region' ancestral to the Gnathostomata. In terms of organization and gene-substitution patterns, the human MHC paralogous region on chromosome 9 is 
conspicuously more similar to the predicted ancestral genomic region than the other three human MHC paralogous regions, suggesting that the entire region may for some reason be under negative selection.

\section{Reporter's comments}

It will be instructive to look at other genomic regions that appear to have a duplication-based origin; this should become more straightforward as the sequenced genomes of other species become available. Such studies should make it possible to trace the type(s) of genome duplication that have occurred in vertebrate evolution - whether complete polyploidization or duplication of chromosomal segments. Further studies might also explore the implications of apparent negative selection pressures for maintaining gene organization within entire genomic regions, as observed here for the MHC region on human chromosome 9. These types of study should help to understand the roles of various genes and gene families in human evolution and development.

\section{Table of links}

Nature\%20Genetics

\section{References}

1. Abi-Rached L, Gilles A, Shiina T, Pontarotti P, Inoko H: Evidence of en bloc duplication in vertebrate genomes. Nat Genet. 2002, 31: 100-105. 